\title{
Counseling Online and Over the Phone: When Preclosing Questions Fail as a Closing Device
}

\author{
Wyke Stommel \\ Center for Language Studies \\ Radboud University Nijmegen, Netherlands \\ Hedwig te Molder \\ Strategic Communication Group \\ Wageningen University, Netherlands; \\ Department of Philosophy \\ University of Twente, Netherlands
}

\begin{abstract}
In this article, we present an analysis of closings in two counseling media: online, text-based exchanges (usually referred to as "chat" sessions) and telephone calls. Previous research has found that the participant who initiated a conversation preferably also initiates its termination with a possible preclosing. Advice acknowledgments, lying in the epistemic domain of the client, are devices that may work as preclosings. However, in text-based chat clients regularly refrain from advice acknowledgment. While counselors use various practices to elicit advice acknowledgment in the context of potential advice resistance, hoaxing, and/or seemingly long pauses, these questions do not always succeed as "closing devices." This offers an explanation for counselors' perception of online chatting as more difficult than calling. The data are in Dutch with English translation.
\end{abstract}

In the Netherlands, information about alcohol and drugs is provided through various media, including several helplines and a national online, text-based service (usually known as a "chat" service) that is accessible through a number of Web sites. These services have the purpose of providing the general population with accurate information about alcohol and drugs. The

We thank Trimbos Institute, and particularly Nathalie Dekker, for the collaboration in and commitment to the research project that resulted in, among other things, this article.

Correpondence should be sent to Wyke Stommel, Center for Language Studies, Radboud University Nijmegen, Postbus 9103, 6500 HD Nijmegen, Netherlands. E-mail: w.stommel@let.ru.nl 
conversations are about (the effects of) problematic drug and alcohol use, treatment options, addicted partners, and many other issues. For our research, we have collaborated directly with the institution that hosts the alcohol and drugs information service (Trimbos Instituut), including the counselors who take the calls and do the chat sessions. The counselors indicated that they often experience the chat sessions as more challenging than the telephone calls. We argue that one reason for this may be the potentially problematic closing of chat sessions.

In this article, we present an analysis of text-based chat session closings. The initiative to close may consist of an action formulation such as "I'll call them on Monday," an epistemic claim such as "I know enough now," or a mental state formulation like "I am reassured now." With these statements, clients acknowledge the advice the counselor provided and thus mark the core institutional activity as being accomplished. Because counselors lack the epistemic right to acknowledge their own advice, it is the client's privilege to initiate the closing of the conversation. In other words, these statements are devices that "work to set up the prospective relevance of terminal adjacency pairs" (Heritage \& Watson, 1979, p. 154). Therefore, they are realizations of the participants' preference for callers (as opposed to the called) to initiate closings (Antaki, 2002). In other words, these utterances have a double interactional function: They treat the provided advice as an answer to their question, and they open up the closing.

In chat sessions, clients also use "preclosing" (Schegloff \& Sacks, 1973) statements. They may send off posts such as "Thank you, I'll read it, thanks for your time." However, they also regularly do not send off a post that works as a preclosing. In those cases, the counselor initiates the closing (in 12 out of 32 sessions), or the session ends without a terminal adjacency pair because the client logs out (in five out of 32 sessions). For counselors having to initiate closing, the problem to be solved is how to move the conversation toward closing while lacking the epistemic authority to acknowledge the advice. This dilemma is at the center of our analysis. We analyze chat session closings with the aim of understanding how chat counseling works potentially different from spoken forms of counseling.

\section{ONLINE COUNSELING}

Generally, online counseling, considered a valuable alternative to face-to-face treatment, seems to be as effective as traditional forms of counseling (Fukkink \& Hermanns, 2009a). It is recognized that online counseling raises some issues unknown to traditional counseling, but advantages such as perceived privacy and an emotionally safe environment seem to outnumber problems (Fukkink \& Hermanns, 2009b; King, Bambling, Lloyd, et al., 2006; King, Bambling, Reid, \& Thomas, 2006). Recently, research into actual online counseling sessions has begun to increase (Danby, Butler, \& Emmison, 2009; Ekberg, Barnes, Kessler, Malpass, \& Shaw, 2013; Harris, Danby, Butler, \& Emmison, 2012; Stommel, 2012; Stommel \& Van Der Houwen, 2013, 2014). These conversation analytic studies focused on issues such as counselors' (affective) responses to clients' problem telling in opening sequences (Danby et al., 2009; Ekberg et al., 2013), counselors' formulations of clients' posts (Stommel \& Van Der Houwen, 2013), counselors' requests to clients to call them (Harris et al., 2012), clients' complaints about online counseling and counselors' responses to these complaints (Stommel \& Van Der Houwen, 2014), and clients' and counselors' recipient design in the way they address each other (Stommel, 2012).

Indirectly, these studies have provided the empirical evidence that online counseling resembles spoken counseling (face-to-face or telephone) in a number of ways. For instance, counselors are 
similarly sensitive to the therapeutic relationship, exhibited in the way they design requests (Harris et al., 2012). Counselors also display empathy online (Ekberg et al., 2013), and they use formulations for similar purposes (Stommel \& Van Der Houwen, 2013). However, these studies have also revealed distinct aspects of online counseling vis-à-vis spoken counseling. Danby et al. (2009) have shown that counselors' formulations of clients' problems in chat counseling are sequentially ambiguous, while they are not in the equivalent calls. Another aspect of online counseling is that clients seem to "use" disrupted turn adjacency (García \& Jacobs, 1999) as a resource to resist counselors' formulations (Stommel \& Van Der Houwen, 2013). Hence, the comparison of online, written forms of counseling and their spoken counterparts seems a productive approach to analyze the affordances (Hutchby, 2001) and drawbacks of online counseling.

\section{CONVERSATIONAL CLOSINGS}

Schegloff and Sacks (1973) revealed how participants accomplish a termination of the turn-byturn course of conversations. They showed that participants use "possible pre-closings" (such as "Well ..." and "OK") to signal that the conversation may approach its ending and that it then involves both speakers to produce a "bye" before the conversation is successfully finalized. These are closing routines that should be understood as follows: "By starting a closing routine, one or other participant offers the other(s) the chance to embark on a line which will eventually allow silence without implication of fault (Antaki, 2002, p. 9). Nevertheless, the phenomenon of closings should not be seen as an automatic routine because "there are possibilities throughout a closing, including the moments after a 'final' good-bye, for re-opening the conversation" (Schegloff \& Sacks, 1973, p. 324). In other words, reaching silence after a conversation is an accomplishment.

\section{CLOSINGS OF ONLINE CONVERSATIONS}

Previous analyses of online interactions (Markman, 2009; Pojanapunya \& Jaroenkitboworn, 2011; Raclaw, 2008) have revealed that closings largely follow the same pattern as in spoken interaction, consisting of a preclosing adjacency pair and a terminating one. However, online preclosings often contain accounts and dispreference markers that are not typically found in spoken closings (Pojanapunya \& Jaroenkitboworn, 2011; Raclaw, 2008). These are related to the possible accountability of a participant "to retain a specific type of availability in the constant online presence afforded by the [Instant Messaging] program" (Raclaw, 2008). It remains to be seen if this perceived availability is explained by the technology itself alone or rather by the relatively unfocused activity of engaging in private IM chat or Second Life role-play. In institutional chat sessions we may expect a more overt relevance of closing.

Markman's (2009) analysis of a virtual team meeting using Web-based chat shows how timing plays a crucial part in the management of the closing. Placing a preclosing turn is difficult because one cannot monitor the typing of the others and hold the conversational floor for the time needed to type the preclosing post. This means the medium of chat is responsible for closing trouble, although the type of difficulties described are likely to be typical for multiparty chat sessions rather than one-to-one text chatting. 


\section{INITIATING CLOSINGS}

Closings may include components that give a "signature' of sorts to the type of conversation" (Schegloff \& Sacks, 1973, p. 318). A component like "Thank you" in the closing phase marks the conversation as one in which one of the participants (most likely the called) has provided the coparticipant with something (e.g., an advice). Closings may also contain institution-specific elements. In medical encounters patients frequently use an "action formulation" to reinforce commitment to an earlier agreed-upon course of action (Gafaranga \& Britten, 2004). Because action formulations are in many cases followed by actual closing of the encounter, they can be seen as "contextualisation cues" (Gumperz, 1982) through which patients indicate the intention to close the interaction.

The fact that action formulations are used by patients rather than by doctors may not be coincidental. As mentioned, it was found that there is a preference for callers rather than the called to initiate closings "to display the minimum imposition on the person he or she has called" (Antaki, 2002, p. 21). Reversely, when the called closes the conversation, the caller may feel "lousy" (Antaki, 2002; Sacks, 1992, Vol. II, p. 366). So apparently there is a norm that says that the one who initiated the conversation should also initiate its closing. But there is an additional dimension to this norm in institutional interaction. Whether the professional's proposal/advice is adequate or not is ultimately something only the client can decide and communicate (Heritage, 2011). Because professionals lack the epistemic authority to claim that clients have been (sufficiently) helped, it is interactionally problematic for professionals to initiate closings. Previous research has identified various practices of how to "solve" this dilemma locally. Heritage and Lindström (1992) found that health visitors built offers onto the advice they dispensed as a "solution," because when mothers acknowledged the health visitors' offers, they implicitly accepted the advice and thus terminated the advice-giving sequence. West (2006) suggested that physicians may reinvocate previously agreed-to arrangements for the same reason, i.e., as a resource for "terminating the interminable" (although she eventually rejects this explanation for doctor's reinvocations of arrangements as closing initiations). Hence, the client's obligation to close is simultaneously an interactional privilege: The professional should respect the client's entitlement to acknowledge the advice. In this article, we analyze the closings of chat counseling conversations in the light of the client's privilege to acknowledge the advice.

\section{DATA AND ANALYTICAL PROCEDURE}

The data of this study consist of 40 phone call recordings of the Trimbos alcohol and drugs information line and 40 chat logs of the Dutch national alcohol and drugs chat information service. Callers and chat clients contact the service for various purposes, such as seeking advice about drugs/ alcohol use, gaining information about professional help or treatment, and seeking support with regard to an addicted partner, etc. Usually, the client introduces one question or one reason for seeking help. The service is available from 2 to 5 p.m. on weekdays. The counselors, who usually have a background in social work, have received training and written guidelines for the chat service and helpline. This includes the instruction to check whether the client has been sufficiently informed and if this gives him/her something to work with, before actively closing the session. The calls have an average duration of approximately $13 \mathrm{~min}$, while the chat sessions last on average approximately $20 \mathrm{~min}$. The chat program includes a sign that indicates when the coparticipant is typing, although 
counselors reported this facility does not always work. The observation of some live chat sessions has revealed that counselors sometimes, but not always, wait for the client's post before typing and/ or sending off a next post. It is likely that clients do the same. According to the chat counselors, time lags hardly ever occur during online chat sessions (see Rintel, Pittam, \& Mulholland, 2003).

The Trimbos Institute records calls and saves chat logs for feedback and training purposes. Because our data collection consists of such "stored" conversations, we could not ask participants for informed consent prior to the study, and they were not asked for consent retrospectively. However, the counselors were all informed about the study and were invited to participate in a user group to take part in hands-on discussion of the materials and analyses. To guarantee the participants' anonymity, one of the counselors selected the calls in which none of participants mentioned anything that could lead to their person. This counselor also collected the chat sessions, replaced names by pseudonyms, and deleted other person-related information. The reason Trimbos Institute was willing to collaborate with us and make available the data was a "practical" interest: We developed a workshop for online counselors from the Trimbos Institute and some other chat services based on our analysis.

Of the 40 chat sessions we obtained, we excluded eight sessions because they involved questions from pupils or students who sought information for school reports. For the 32 sessions, it was hard to distinguish whether clients asked for information only or also for advice. For instance, a client would ask "Is it possible to commit suicide with a high dose of ecstasy?" This question is designed as a question for information, but it could be treated as soliciting advice about suicide and ecstasy. In the analysis, we therefore use the more inclusive term advice.

The chat sessions we analyzed involved 21 counselors and 32 clients. In our data set, it appeared that individual counselors did not use the same preclosing question consistently. Of the 40 calls, four turned out to be incomplete calls or damaged audio files. The exact number of phone counselors of our 36 calls is untraceable because they did not always say their name on the phone. To protect the counselors' identity, we have not otherwise looked for information on the counselors.

The analytical procedure we followed for the study is the conversation analytical question "Why that now?," which is the analytical starting point for examining talk (Heritage \& Clayman, 2010). In chat, the "now" refers to each post in relation to the previous and "that" to the design of the post. This means we viewed each post as shaping the context for the next post and being shaped by the previous post (Vayreda \& Antaki, 2009), unless there were strong indications of simultaneous post construction and consequent disrupted turn adjacency.

For each chat log, we treated utterances that could potentially be read and taken as advice acknowledgments, as constituting the first possible turn to the (pre)closing.

\section{ANALYSIS}

Closing the online chat session may involve various counselors' practices that serve as a catalyst for terminating the session. We want to show one example of a call from the helpline, to illustrate the privilege for the caller to initiate the closing (Antaki, 2002). Excerpt 1 is taken from a call about a strong smell of cannabis around and in the caller's house, probably caused by an illegal cannabis plantation in the neighborhood. The caller wonders whether the smell is dangerous to her newborn. The assessment ("really annoying") in line 1 refers to the fact that opening the windows does not help. 


\section{Excerpt 1 (P.123/ tel 27)}

$1 \mathrm{Cl}$ : ja das heel vervelend; yes that's really annoying;

2 nou maar dann eeh ja; well but thenn uhh yes;

3 ga ik es effe kijken of ik effe bij de huisarts nog terecht kan I'll just check out if I can quickly get an appointment at the GP

$4 \quad{ }^{\circ}$ voor de zekerheid ${ }^{\circ}$;

just to be sure;

5 Co: $\uparrow$ okee;

$\uparrow$ okay;

6 nou $=$

well $=$

$7 \mathrm{Cl}:=$ dan eeh -

= then uhh-

$8 \quad(0.8)$

$9 \quad>$ oke. $<$

$>$ okay. $<$

10 maar dan $>$ weet ik in ieder geval $<$ dat het niet heel erg schadelijk but then $>$ at least I know< it is not very harmful;

11 is;

$12 \quad{ }^{\circ}$ dat scheelt. ${ }^{\circ}$

13 Co: ja.

${ }^{\circ}$ that makes a difference. ${ }^{\circ}$

yes.

14 daar- dAAr $>$ hoef je je in ieder geval $<$ geen zorgen over te that- that you don't have to worry about anyway

15 maken.

$16 \mathrm{Cl}$ : oke.

okay.

17 dat [is fijn.

that ['s good.

$18 \mathrm{Co}$ : [ja?

[yes?

$19 \uparrow \mathrm{o}[\mathrm{ke}$.

$\uparrow o[k a y$.

$20 \mathrm{Cl}$ [nou;

[well;

21 is goed,

good,

22 bedankt voor de informatie;

thanks for the information;

23 Co: graag gedaan,

you're welcome,

$24 \mathrm{Cl}$ : oke be[dankt ja.

okay [thanks yeah.

25 Co: [daag.

[bye. 
The caller produces an action formulation (lines 2-4), saying she will check with the physician whether the smell is not harmful for her baby. In response, the counselor agrees with this action proposal (line 5) and takes the next step toward the termination of the call with "well ..." (line 6). In other words, the action formulation turns out to be a preclosing (Schegloff \& Sacks, 1973). With an acknowledgment of the information she received from the counselor (that the smell is at least not very harmful), the caller assures the call has been helpful ("that makes a difference," line 12). The partial repeat of the advice (lines 10-11) is a "marked acknowledgment" (Heritage \& Sefi, 1992), which is common in calls in which the client already cast herself in the role of prospective advice recipient by directly requesting advice in the beginning of the call. The counselor, in response, agrees with the advice repeat (line 13) and makes explicit that this information takes away the client's worries (lines 14-15). The counselor thus orients to her complementary role as advice provider. The caller next assesses this as "good" (line 17), exhibiting in a different fashion that the call reassured her and the counselor's response. Next, "yes? $\uparrow$ okay." (lines 18-19) closes the preclosing sequence. So, the caller initiated the closing with an action formulation and an epistemically explicit advice acknowledgment ("but then at least I know," line 10). The counselor also oriented to the norm that these preclosing statements are relevant at this point, thereby respecting the client's privilege to initiate closing. The fact that in our data, call closings are overwhelmingly initiated by the caller confirms the idea that the caller's behavior is normative (see Antaki, 2002). Many chat closings (15/32) are similarly initiated by the client.

However, chat closings also regularly lack an advice acknowledgment that is sufficient to work as a preclosing. As a result, the counselor should find an exit to the chat session while respecting the caller's privilege to acknowledge the advice. One solution would be to just wait until the client posts such a message. However, this may involve seemingly endless silences and no guarantee that the client (eventually) will produce an acknowledgment. A common "solution" to this dilemma is to elicit an advice acknowledgment with a preclosing question. We found three types of possible preclosings: (a) questions projecting the client's future action ("Does that give you something to work with?") (six times in 12 sessions), (b) elicitations of direct advice acknowledgment ("I hope you know enough now") (seven times in 12 sessions), (c) offers of a new advice sequence ("Do you have any other questions?") (six times in 12 sessions). We first illustrate and analyze these preclosing questions. Then we discuss some instances where such questions fail to work as preclosings, namely in the context of potential advice resistance and hoaxing.

\section{PRACTICE 1: PROJECTING THE CLIENT'S FUTURE ACTION}

In Excerpt 2, the client does not spontaneously acknowledge the advice about how to deal with her son's marijuana use. Then the counselor asks if the client now knows what to do. In her next post, the client treats this question as a preclosing. Note that the Dutch posts are original; language mistakes from the participants have been preserved. The time stamps in the excerpts refer to the actual time; they do not indicate how long the session has already been going on. 


\section{Excerpt 2 (P.113/Chat 37)}

1 [15:55:01] Co: zorg eerst zelf voor voldoende info en ga dan een

first make sure you have enough information and then start a

2 gesprek aan, afspraken kan je maken over de zaken die conversation, you can come to a mutual agreement about issues that mischien reeds eerder aan de orde zijn geweest perhaps have been discussed already

4 [15:56:21] Co: bv ook over stiekem gedrag, vraag waarom en geef dan aan e.g also about secretive behaviour, ask why and indicate liever erover in gesprek te gaan that you prefer to talk about it

6 [15:57:30] Co: op de site van het drugsinfoteam vindt $u$ hier meer tips on the site of the drugs info team you'll find more tips

7 en adviezen over and advice on this matter

8 [15:58:13] Co: Kun je hiermee verder? Does that give you something to work with?

9 [15:58:41] Cl: Ja, dank U wel. Yes, thank you.

10 [15:58:59] Co: Ik wens je veel succes en je kunt altijd nog eens I wish you good luck and you can always

11 terugkomen come back

In the first three posts of this excerpt (lines 1-7), the counselor provides advice about quitting drug use. There are long pauses in between the three posts (1:20 after line 3, 1:09 after line 5, 0:43 after line 7) in which the client does not post a response. At least the two pauses of over $1 \mathrm{~min}$ are very likely to be longer than the counselor needed to compose the posts. Therefore, it is unlikely the client was waiting for the posts due to the typing indication on the screen. Hence, the nonresponses after lines 3 and 5 (and arguably after 7) are ambiguous (Rintel et al., 2003); they could be related to multitasking, to unfamiliarity with the medium, or passive resistance to the advice. The counselor then elicits an advice acknowledgment (line 8), which can be seen as a response pursuit displaying the preference for answers, even disaligning ones, over nonanswer responses (Stivers \& Robinson, 2006). The question refers to the help seeker's possibilities for action after the interaction and takes into account the client's privilege to produce an advice acknowledgment. The confirmation ("Yes," line 9) including a final "thank you" follows fairly quickly (0:28). In doing so, the client takes up the counselor's question as an invitation to produce a preclosing. This is then treated as sufficient grounds to end the session (line 10), again rather swiftly (0:18).

Hence, in chat sessions, counselors may deal with long pauses and lacking advice acknowledgment by posting a preclosing question that pursues a response and moves toward closing the session, while recognizing the client's entitlement to decide whether the advice was adequate to him/her.

\section{PRACTICE 2: ELICITING A DIRECT ADVICE ACKNOWLEDGMENT}

Even if the help seeker has already implicitly acknowledged the advice, the counselor may have to elicit an explicit acknowledgment in order to move the interaction toward closing. Excerpt 3 is 
taken from a chat session with a help seeker who wonders whether it is better to stop drinking completely or to reduce it. Toward the end the counselor formulates hope concerning the helpfulness of the session that makes relevant a confirmation.

\section{Excerpt 3 (P. 109/Chat 33)}

1 [14:30:18] Cl: mee eens, heb ik dat in ieder geval helder agreed, at least that's cleared up

2 [14:30:45] Co: Nou dat is mooi $\left.{ }^{\wedge} \mathrm{O}\right)^{1}$

Well that's great $\left.\wedge^{\wedge}\right)^{1}$

3 [14:31:08] Co: Ik hoop dat je hiermee uit de voeten kunt en dat je

I hope that you can work with this and that you

4 antwoord op je vraag hebt gekregen? got an answer to your question?

5 [14:31:58] Cl: 1 vraag nog; zou je afbouwen of opeens stoppen?

1 more question: would you cut down or quit cold turkey?

$6 \quad$ [14:32:41] Co: Gewoon stoppen!

Just quit!

7 [14:34:16] $\mathrm{Cl}:$ dankjewel, $\mathrm{Co}$, ik ga een plan maken. ben overigens

thanks, Co, I'm gonna make a plan. by the way

8 gisteren begonnen met stoppen dus vanavond I started quitting yesterday so tonight

9 zitten de 1 e 48 uur erop. the $1^{\text {st }} 48$ hours are done.

10 [14:34:41] Co: Nou hartstikke mooi, doe je best en veel succes!

Well that's great, try your best and good luck!

11 [14:35:30] $\mathrm{Cl}$ : nogmaals dank en fijne dag verder

thanks again and have a good day

12 [14:35:31] Cl: Doeg

Bye

13 [14:36:47] Co: doeg,

bye,

About 25 min into the chat session, the help seeker suggests that he would first try to stop completely and later try to restrict it to weekends, which the counselor first assesses as a good plan and then formulates as a quitting strategy (data not shown). The client agrees with the counselor's formulation with an epistemic claim (line 1), implicitly acknowledging the chat session provided this knowledge. The counselor responds with an assessment ("Well that's great ${ }^{\wedge} \mathrm{o}$ )"), which can be read as a positive conclusion to the chat session without trespassing the client's privilege to advice acknowledgment. However, this assessment fails to make relevant an acknowledging preclosing statement from the client. The counselor solves this apparent interactional impasse with a formulation of hope concerning the helpfulness of the chat session, which is designed as preferring an agreement and thus an advice acknowledgment (lines $3-4){ }^{2}$ At first sight, this post seems to fail in its attempt to move

\footnotetext{
${ }^{1}$ The meaning of the emoticon “^ $\mathrm{O}$ )" is unclear. It may contain a typing error and be intended as “^ $\mathrm{O}^{\wedge}$, which means happy or joyful.

${ }^{2}$ Syntactically, this post consists of an assertion, but the question mark renders an agreement particularly relevant (see Stommel \& Van Der Houwen, 2013).
} 
toward termination because the client posts another request for advice (line 5). The design of the request, however (explicit reference to being " 1 " question and the "or"-question), and the advice that follows ("Just quit!") are oriented to a due closing. It takes 1:35 before the client acknowledges the advice, but in this particular chat session pauses between posts from both participants are often over $1 \mathrm{~min}$, so this may explain why the counselor does not treat the delay as advice resistance. Eventually, the client explicitly acknowledges the advice (line 7) and thus actively proceeds toward the end of the chat session.

\section{PRACTICE 3: OFFERING A NEW ADVICE SEQUENCE}

In some cases, the counselor does not elicit an advice acknowledgment but invites the introduction of other questions or concerns (e.g., "Do you have any other questions?"). In medical encounters, "Anything else?" communicates a contingent shift into closing. As it is designed to receive "no" as an answer, the patient's answer constitutes the ground for closing (Robinson, 2001). In the chat sessions, counselors produce this question when either the client or the counselor treats the advice as potentially insufficient or when it is met with resistance. In Excerpt 4, the counselor gives information about alcohol and getting drunk.

\section{Excerpt 4 (P.97/Chat 20)}

1 [13:39:11] Co: Dus vanag een glas of 3-4 ben je echt wel merkbaar onder

2 So from about 3-4 glasses you are noticeably under invloed

3 [13:39:27] Co: Is dat een beetje een antwoord op je vraag? Does that more or less answer your question?

4 [13:40:19] $\mathrm{Cl}$ : okee dat was mij vraag ik drink niet elk weekend maar zo okay that was my question I don't drink every weekend but

5 af en toe met vrinden heb ik ook een vraag over roken every now and then with friends I also have a question about smoking

6 [13:40:38] Co: stel je vraag maar dan:)

then go ahead with the question:)

7 $<19$ posts omitted $>$

8 [13:49:28] Co: hierna moet je de gewoonte van het roken afleren,

9 dat duurt wat langer that takes a little longer

10 [13:49:44] $\mathrm{Cl}$ : oke dat was me vragen okay those were my questions

11 [13:50:02] Co: ok fijn, ik hoop dat je nu genoeg weet okay great, I hope you know enough now

12 [13:50:10] Co: veel succes met stoppen met roken;) good luck quitting smoking;)

13 [13:50:19] $\mathrm{Cl}$ : ok dank u wel ok thank you

14 [13:50:23] Co: heb je nog meer vragen? do you have any other questions? 


\begin{tabular}{|c|c|c|}
\hline [13:50:28] & $\mathrm{Cl}:$ & $\begin{array}{l}\text { niet meer } \\
\text { no more }\end{array}$ \\
\hline$[13: 50: 37]$ & Co: & $\begin{array}{l}\text { ok, fijn dat ik je kon helpen } \\
\text { ok, I'm glad I could help you }\end{array}$ \\
\hline$[13: 50: 43]$ & $\mathrm{Cl}:$ & $\begin{array}{l}\text { ok } \\
o k\end{array}$ \\
\hline$[13: 50: 47]$ & Co: & $\begin{array}{l}\text { ok doei } \\
\text { ok bye }\end{array}$ \\
\hline$[13: 50: 52]$ & $\mathrm{Cl}:$ & $\begin{array}{l}\text { doei } \\
\text { bye }\end{array}$ \\
\hline
\end{tabular}

The advice (lines 1-2) is not immediately responded to by the client. The question "Does that more or less answer your question?" (line 3) makes relevant an advice acknowledgment, but possibly due to the participants' simultaneous post construction (García \& Jacobs, 1999) the client's next post is not a response to line 3 . The client only indirectly acknowledges the advice ("okay that was my question," line 4) and posts a second question, about smoking (lines 6-9). Then, the session continues on the topic of quitting smoking. The client closes the smoking advice sequence by claiming those were his questions (line 10), without an acknowledgment of the answers he received. Although this could have been interpreted as resistance, the counselor does not treat it as such. He formulates hope concerning the epistemic valence of the advice (line 11$)^{3}$ and in a quick next post wishes the client success (line 12). The client's "ok thank you" (line 13) could have been treated as a preclosing, but conversely, the counselor invites other questions (line 14). This may be related to the fact that the client had already posed a second question but also to the absence of an explicit advice acknowledgment. The preferred answer ("no") progresses the conversation toward its termination (Robinson, 2001). The counselor then explicates the value of having been able to help (line 16), underscoring the relevance of advice acknowledgments. In other words, the counselor first makes relevant a response that implies the client has been helped and then formulates that he is glad he could help. This seems an interactional solution to deal with potential advice resistance, while at the same time constituting a move toward the closing of the session. In terms of pacing (the posts being about 5-10 s apart) and alternating turn taking, this closing shows a clear coconstruction and can therefore be seen as relatively unproblematic compared to some others.

Excerpt 5 is a case of potential advice resistance that is solved with the offer of a new advice sequence. The client's initial question is where he could grow ketamine (note, however, that ketamine is a synthetic drug that cannot be grown). The counselor refers to a Web site about ketamine, but this is insufficient ("that doesn't help me, I can't find anything there about growing"). Then the counselor offers a phone number for more information about ketamine (lines 1-2).

\footnotetext{
${ }^{3}$ Had the counselor not sent the "good luck" so quickly, the hope-formulation could have elicited an implicit advice acknowledgment (cf. practice 2).
} 


\section{Excerpt 5 (P.107/Chat 31)}

1 [15:37:56] Co: mocht je meer willen weten over ketamine, dan kun je in case you want to know more about ketamine, you can

2

3 [15:38:32] $\mathrm{Cl}:$ ok3 bellen met het volgende telefoonnummer 0900-[xxxx] call the following number 0900-[xxxx]

$4-[15 \cdot 38 \cdot 37]-\mathrm{Cl}^{2} \cdot \mathrm{ok}^{*}$

4 [15:38:37] Cl: $\mathrm{OK}^{*}$

5 [15:39:25] Co: kan ik verder nog iets voor je doen?

$6 \quad[15: 39: 40] \quad \mathrm{Cl}: \mathrm{Nei}$ is there anything else I can do for you? No

7 [15:40:30] Co: ok, prima, dan sluit ik het af. Succes

$8 \quad[15: 40: 54] \mathrm{Cl}: \quad \begin{aligned} & o k \\ & \mathrm{Ok}\end{aligned}$ ok, fine, then I'll close now. Good luck

9 [15:40:54] Cl: Houdoe take care

10 [15:41:02] Co: tot ziens goodbye

11 [15:41:06] Cl: Houdoe take care

As said, the advice in lines 1-2 follows the client's rejection of the first piece of advice (data not shown). The design of the advice ("in case you want to know more") constructs it as additional advice rather than as a new attempt to provide the relevant advice. This suggests that the counselor has already provided the client with sufficient information, which is protective of the counselor. The client's response is a minimal advice acknowledgment ("ok" in line 3 and a spelling repair in line 4) that could be explained as skepticism and/or resistance to this additional advice. However, the counselor seems to have provided all disposable answers to the help question but cannot just close the session. She waits $48 \mathrm{~s}$, apparently due to the ambiguity of the minimal acknowledgment and following pause, and then posts an offer of a new advice sequence. This closes the topic of ketamine without dealing with the (potential) resistance of the "ok" (lines 3 and 4). The client's "no" (line 6) in response is again minimal and thus resistant (not followed by a "thank you" or some other closing device). Now, the counselor waits $50 \mathrm{~s}$ and then treats the "no" as sufficient to announce that she will close the session (line 7). The final closing "Good luck" (line 7) at the end of this post is followed by an alternating turn-taking closing pattern with brief pauses $(0: 14,0: 06,0: 04)$. So in this session minimal responses and long pauses are treated as advice resistance, and an offer of a new advice sequence is produced to deal with this.

This question is a notably different practice compared to the other two practices where an agreement in response implicates an advice acknowledgment. The offer of a new advice sequence puts aside the relevance of advice acknowledgment and may thus mask that the advice was resisted. 


\section{PRECLOSING QUESTIONS AS FAILING CLOSING DEVICE}

A recurring question in counseling helplines (chat and phone) is whether the help seeker is genuine (see Emmison \& Danby, 2007). As soon as counselors are certain (enough) that they are dealing with a hoax call/chat session, they attempt to close the call/session. However, counselors agree that frequently there is a "real" question behind the pretended one. Cutting off the conversation too quickly or accusing the client of insincerity would expel a member of the target group and is therefore counterproductive. In other words, the dilemma is how to provide advice in situations where the sincerity of the help seeker is doubtful. One way to deal with this dilemma is to end the session as soon as possible, namely, soon after the advice has been communicated. Then, a preclosing question may be mobilized as a closing device. This is illustrated with Excerpt 6 .

\section{Excerpt 6 (P.106/Chat 30)}

1 [13:28:19] $\mathrm{Cl}$ : dit het ik wel is geprobeert is het schadelijker als

I have tried this once is it more harmful

2 je stoned vrijt

to have sex when you're stoned

3 [13:30:02] Co: je kunt opgegeven moment ook slechter dingen als at a certain point you can also have trouble onhouden en moeite hebben met concentreren,vrijen remembering and concentrating, having sex onder invloedd van wiet zou schadelijk kunnen zijn under the influence of weed could be harmful als er een zwangerschap door ontstaat if it leads to a pregnancy

7 [13:30:26] $\mathrm{Cl}$ : ik ben 15 heeft $\mathrm{u}$ dit ook wel is mee gemaakt I am 15 did you ever experience this

8 [13:30:46] Co: schade voor de baby, voor je zelf is het belangrijk harm to the baby, for you it is important om te zorgen voor veilig vrijen to make sure you have safe sex

10 [13:31:03] $\mathrm{Cl}$ : maar zonder vind ik lekkerder but I prefer to have sex without

11 [13:32:29] Co: ja, dit heb ik eerder meegemaakt, zonder condoom yes, I have experienced this before, having sex vrijen is lekker voor velen, maar wie wil nou without a condom is good for a lot of people, but who wants mogelijke problemen als soa,s possible problems like STDs

14 [13:33:00] Co: Heb ik zo antwoord gegeven op je vragen? Have I answered your questions like this?

15 [13:33:17] Cl: ja maar als je het allebei niet hebt kan het niet yes but if neither of you have them they can't

$16 \quad$ ontstaan toch? emerge right?

17 [13:34:40] Co: dat klopt, als je een vaste partner hebt, kan het that's right, if you have a steady partner, risico lager zijn. [...] the risk can be reduced.[...] 
Prior to where the excerpt begins, the client has asked the counselor about the influence of drugs (being stoned) on the body. This issue evolves into the client's question about drugs and sex (line 1). The client is provocative in asking whether the counselor has experienced "this" herself (line 7), with "having sex under the influence of weed" (lines 4-5) as its most likely antecedent. Personal questions like this transgress the norm that institutional interaction is about the client, not the professional (Te Molder, 2005). Then, the client again provokes the counselor by countering her advice of safe sex with the claim he prefers unsafe sex (line 10). After a long pause (1:26), the counselor surpasses the transgressive question by interpreting it as referring to the experience of having ever dealt with this question as a counselor (instead of her own experience of having sex under the influence of drugs) and brings in a counterargument with "but" (line 12). She then does not wait for an advice acknowledgment (note the short 0:31 pause here compared to the 1:26 between lines 10 and 11) and posts a preclosing question, steering toward termination of the chat session (line 14). However, the client then posts a new argument ("yes but") to the discussion about unsafe sex (lines 15-16). Possibly, the client was typing simultaneously or had not read the counselor's post in line 14 as he started constructing his new post (lines 15-16), but he treats the preclosing question as "sequentially nonconsequential" (Schegloff, 1987, p. 110). The counselor, in response, does not initiate a repair (see Schönfeldt \& Golato, 2003) of the client's nonanswer to her question but responds on the topic of lines 15-16. Hence, the preclosing question, always being contingent on the client's response, has failed in its attempt to push the session toward closing. It was arguably mobilized to find an exit to the session with a potentially pretending client, while respecting the client's entitlement to treat a possible preclosing as a preclosing. The actual closing of this session is presented as Excerpt 8 .

Excerpt 7 is another example of a preclosing question failing to work as a closing device. Here, the client's "advice recipiency" is at issue, rather than the client's sincerity. The client used ecstasy (XTC) a couple of days before the session and now feels very bad. In the course of the chat session, the counselor has reassured the client (given information about ecstasy, claimed that "nothing much" can happen anymore), but the client resists this.

\section{Excerpt 7 (P.78/Chat 1)}

1 [16:54:12] Co: oei rot voor je, xtc werkt op je spierspanning, en kan ohh I'm sorry for you, xtc affects your muscle tension,

2

3

4

5

6

7 bij overmatig ( 2 is een beetje veel) tot uitdroging and when used excessively ( 2 is a bit much) can lead to dehydration leiden, goed drinken is het advies, (water dus, maar drinking plenty is the advice, (water that is, but niet meer dan om het uur een glas, goed eten, even goed no more than one glass every hour, eat well, have a slapen, en dan moet gaat het voorbij. anders volgende good sleep, and then it should pass. otherwise go see week toch nog eens naar je huisarts voor verder your physician next week for further onderzoek examination 
8 [16:54:38] $\mathrm{Cl}$ : oki ma je ken niet meer dood gaan na 1 week lang

ok but you can't die anymore after 1 week

9 [16:54:43] $\mathrm{Cl}$ : omdat dit gevoel al 1 week lang heb

because I have had this feeling for a week already

10 [16:54:44] Co: nee hoor

no don't worry

11 [16:54:47] $\mathrm{Cl}:$ Oki

Ok

12 [16:55:25] Co: Oke, heb ik je een beetje gerustgesteld, beetje

Okay, have I reassured you a little bit, take it

13

rustig aan met alcohol ook, maar dat doe je

easy with alcohol also, but you probably are

14

waarschijnlijk al. raad je aan om even gezond te doen.

already. advise you to live healthy for a little while.

15 [16:55:30] $\mathrm{Cl}$ : ken er aleen die avend zelf dan wat met je gebeuren so only on the night itself it is possible that something happens to you

16 [16:55:39] Co: ja dat kan

yes that's possible

The counselor's response to a series of client posts, with details of her complaints, is composed of various actions (lines 1-7): empathic assessment ("ohh I'm sorry for you"), information about the effects of ecstasy, advice (drink lots of water, etc.), and finally reassurance that if the client follows the advice the symptoms will disappear. However, the client resists the reassurance ("ok but," line 8) and asks about potential late effects of ecstasy, an issue not addressed by the counselor yet. The counselor denies these late effects (line 10), which exhibits a second instance of reassurance. This is received with a minimal advice acknowledgment ("ok," line 11). The counselor's next post (line 12) starts with the question whether she has been able to reassure the client ("Okay, have I reassured you a little bit"), inviting a more explicit advice acknowledgment than the "ok" in line 11. The continuation of the post are chunks of advice, which are designed and positioned (following the preclosing question) as additional, final advice in the service of (pre) closing. While the counselor was constructing this long post, the client was likely to be simultaneously typing her next post (line 15) because the time difference is only 0:05 (compared to 0:26 before line 8 ). The client (line 15) rephrases the question posted in lines 5-6 and thus treats the reassurance in line 10 as insufficient. After line 16, the session continues for more than $11 \mathrm{~min}$, in which the client is still seeking reassurance. So, the preclosing question plus additional advice (lines 9-10) fail to work as a closing device, due to simultaneous post construction. ${ }^{4}$

The last example in Excerpt 8 is another example of how questions in the purpose of closing chat counseling conversations may be insufficiently forceful, at least in chat, to push the client to cooperate in the coconstruction of a closing. The excerpt is taken from the same "hoax" session as Excerpt 6.

\footnotetext{
${ }^{4}$ The counselor does not produce another preclosing question to eventually close the session, but she uses extreme case formulations to rephrase her reassurance ("it will really be ok," "really nothing could go wrong now"), which finally receives a "thank you" from the client.
} 


\section{Excerpt 8 (P.106/Chat 30)}

$1 \quad$ [13:43:28] Co: als je ervan af wil kan je contact opnemen met een if you want to get rid of it you can contact an instelling voor verslavingszorg bij jou in de regio, institution for addiction care in your region, kijk op sites van brijder, jellinek, tactus ${ }^{5}$ en verder check out sites of brijder, jellinek, tactus and also op drugsinfo.nl voor meer informatie, we kunnen hulp drugsinfo.nl for more information, we can

offer tailored care

6 [13:44:22] Co: Heb ik zo antwoord gegeven op je vragen? Have I answered your questions like this?

7 [13:44:29] Co: Kun je hiermee verder?

$8 \quad[13: 46: 37]$ Co: ?? Does that give you something to work with?

$9 \quad[13: 46: 55] \quad \mathrm{Cl}:$ Jaaa Yesss

10 [13:47:44] Co: heb je zo voldoende info, of is er nog iets anders so do you have enough info, or is there anything else

11 [13:49:01] Co: Ik wens je veel succes en je kunt altijd nog eens I wish you good luck and you can always terugkomen. come back again.

The advice in lines 1-5 refers the client to clinics and Web sites for information and advice on reducing/quitting drug use. The "if-then" construction through which the advice is delivered reduces the relevance of an advice acknowledgment because it leaves the responsibility for following the advice with the client (Sneijder \& Te Molder, 2005). After 0:54, the client has not acknowledged the advice, while earlier responses came within approximately 25 s. The counselor posts a possible preclosing question (line 6), which is followed immediately (0:07 later) by another one (line 7). Then, the counselor waits for a reply for more than $2 \mathrm{~min}$, until she pursues a response (line 8). In chat, $2 \mathrm{~min}$ is extremely long to wait for an answer, raising the question of the client's presence, which explains the unspecified design (“??"). The agreement finally produced by the client ("yesss," line 9) is interpretable as advice resistant: slightly sarcastic and only a minimal advice acknowledgment. The counselor then waits long again (1:26) until she mobilizes another possible preclosing question (line 10). After another long silence (1:17), she finally closes the session unilaterally (lines 11-12), which seems justified by the long pauses. In spite of various attempts to respect the client's privilege to acknowledge the advice, the counselor does not succeed in achieving a coconstructed closing.

\footnotetext{
${ }^{5}$ These names refer to institutions for addiction care in the Netherlands.
} 


\section{DISCUSSION}

The analysis of online chat counseling closings sheds an empirically grounded light on what the online counseling literature calls counselors' "extra effort" (Schalken et al., 2010) in chat vis-á-vis spoken counseling. It should be kept in mind, however, that in the majority of our chat sessions, the client does initiate the closing with an advice acknowledgment. This means that text chat sessions frequently resemble calls in the way they are terminated. However, the finding that certain chat sessions end distinctly differently must somehow be related to the characteristics of text chat communication. One explanation lies in the role of pauses in between chat posts. These are much longer than the usual silences between spoken turns, and their nature is different: Users may be typing or repairing typed text (García \& Jacobs, 1999; Meredith \& Stokoe, 2014), they may be involved in multiple (chat) conversations and other activities at the same time (multitasking), the Internet connection may be slow, etc. However, the multi-interpretability of pauses has different consequences for counselors and clients. For example, only a counselor may interpret a long pause as advice resistance. As a consequence, s/he may wait for a next post from the client, but when this stays out, the preclosing question offers a way toward closure. Even when a reply is expected from the caller, a lengthy pause in the chat session may create the need for the counselor to post again. What counts as a long pause varies among chat sessions because each session seems to develop its own posting rhythm.

In the context of (potential) hoaxing, preclosing questions are mobilized quickly after the advice post, not waiting for another response from the client. However, irrespective of their timing, preclosing questions are not always successful as an exit strategy because they do not necessarily receive answers that move the session toward closing. The latter may be related to simultaneous post construction, but it could also be that the questions are simply ignored.

As a consequence, the counselor's position in online chat counseling seems interactionally more fragile than the client's, at least at this point. This could explain why some counselors experience chatting with clients as less satisfying than answering calls. Seen from a client perspective, however, it could also offer an additional explanation for the attractiveness of online chat. Simply put: One of the affordances of text chatting is that the advice can be more easily resisted.

\section{CONCLUSION}

We started our analysis with reference to the preference that in calls, the caller initiates the closing (Antaki, 2002), which is confirmed by our telephone counseling data. In text chat, clients sometimes neglect to initiate the closing, after which counselors may elicit advice acknowledgments. We analyzed these elicitations as a solution to the dilemma that counselors cannot initiate closings because clients are privileged to acknowledge the advice. Previous research already identified several devices that professionals may employ to elicit these acknowledgments (Heritage \& Lindström, 1992; cf. West, 2006). Our analysis demonstrates three additional practices, namely, different questions and formulations used by counselors to elicit acknowledgments: (a) questions projecting the client's future action, (b) elicitations of 
direct advice acknowledgment, and (c) offers of a new advice sequence. We also observed that these devices are not always successful in directing the conversation toward closing. In those cases simultaneous post construction may be (exploited as) a resource for ignoring the sequential relevance of a response to, and alignment with, the preclosing question (Excerpts 6 and 7). Preclosing actions may, however, also be disregarded for reasons unknown (Excerpt 8). Compared with telephone counseling, it seems easier for clients to refrain from advice acknowledgment, probably because the reasons as to why acknowledgments are not given can be manifold. This creates the flexibility to leave acknowledgments out, making it more difficult for the counselor to hold clients accountable for not providing them. Therefore, preclosing actions are relatively forceful (being designed as preferring answers that imply advice acknowledgment) but remain possible preclosings. In the most extreme case, they are not responded to, and counselors find themselves in the position where they have no other option than to close the session unilaterally (Excerpt 8). Closing a session without the client's advice acknowledgment means that the interaction has potentially failed to provide relevant information or advice. This may explain why counselors put quite a lot of effort in eliciting, even repeatedly, an advice acknowledgment. So preclosing questions can interactionally solve the dilemma for counselors to initiate an exit from the session without having to claim access to the client's territory of knowledge. Although they appear to be relatively strong devices, the medium of online chat sessions also enables clients to resist them and thus refuse cooperation in closing the sessions.

\section{FUNDING}

This work was supported by the Dutch Organization for Academic Research [Nederlandse Organisatie voor Wetenschappelijk Onderzoek] (NWO) program Comprehensive Language Use (project BGRK-11-06).

\section{REFERENCES}

Antaki, C. (2002). "Lovely": Turn-initial high-grade assessments in telephone closings. Discourse Studies, 4, 5-23. doi:10.1177/14614456020040010101

Danby, S., Butler, C., \& Emmison, M. (2009). When "listeners can't talk": Comparing active listening in opening sequences of telephone and online counseling. Australian Journal of Communication, 36(3), 91-113.

Ekberg, S., Barnes, R., Kessler, D., Malpass, A., \& Shaw, A. (2013). Managing the therapeutic relationship in online cognitive behavioural therapy for depression: Therapists' treatment of clients' contributions. Language@Internet, 10 (Article 4). Retrieved from http://www.languageatinternet.org/articles/2013/Ekberg

Emmison, M., \& Danby, S. (2007). Who's the friend in the background? Interactional strategies in determining authenticity in calls to a national children's helpline. Australian Review of Applied Linguistics, 30(3), 31.31-31.17.

Fukkink, R., \& Hermanns, J. (2009a). Children's experiences with chat support and telephone support. Journal of Child Psychology and Psychiatry, 50, 759-766. doi:10.1111/jcpp.2009.50.issue-6

Fukkink, R., \& Hermanns, J. (2009b). Counseling children at a helpline: Chatting or calling? Journal of Community Psychology, 37, 939-948. doi:10.1002/jcop.v37:8

Gafaranga, J., \& Britten, N. (2004). Formulation in general practice consultations. TEXT, 24(2), 147-170. 
García, A. C., \& Jacobs, J. B. (1999). The eyes of the beholder: Understanding the turn-taking system in quasisynchronous computer-mediated communication. Research on Language and Social Interaction, 32, 337-367. doi:10.1207/S15327973rls3204 2

Gumperz, J. J. (1982). Discourse strategies. Cambridge, England: Cambridge University Press.

Harris, J., Danby, S., Butler, C., \& Emmison, M. (2012). Extending client-centered support: Counselors' proposals to shift from e-mail to telephone counseling. Text \& Talk-An Interdisciplinary Journal of Language, Discourse \& Communication Studies, 32, 21-37. doi:10.1515/text-2012-0002

Heritage, J. (2011). Territories of knowledge, territories of experience: Empathic moments in interaction. In T. Stivers, L. Mondada, \& J. Steensig (Eds.), The morality of knowledge in conversation (pp. 159-183). Cambridge, England: Cambridge University Press.

Heritage, J., \& Clayman, S. (2010). Talk in action: Interactions, identities and institutions. Oxford, England: Blackwell.

Heritage, J., \& Lindström, A. (1992, August). Advice-giving: Terminable and interminable. Paper presented at the International Conference on Discourse and the Professions, Uppsala, Sweden.

Heritage, J., \& Sefi, S. (1992). Dilemmas of advice: Aspects of the delivery and reception of advice in interactions between health visitors and first time mothers. In P. Drew \& J. Heritage (Eds.), Talk at work: Interaction in institutional settings (pp. 359-419). Cambridge, England: Cambridge University Press.

Heritage, J., \& Watson, D. (1979). Formulations as conversational objects. In G. Psathas (Ed.), Everyday language (pp. 123-162). Hillsday, NJ: Lawrence Erlbaum.

Hutchby, I. (2001). Conversation and technology: From the telephone to the internet. Cambridge, England: Polity Press.

King, R., Bambling, M., Lloyd, C., Gomurra, R., Smith, S., Reid, W., \& Wegner, K. (2006a). Online counseling: The motives and experiences of young people who choose the Internet instead of face to face or telephone counseling. Counseling and Psychotherapy Research, 6(3), 169-174. doi:10.1080/14733140600848179

King, R., Bambling, M., Reid, W., \& Thomas, I. (2006b). Telephone and online counseling for young people: A naturalistic comparison of session outcome, session impact and therapeutic alliance. Counseling and Psychotherapy Research, 6(3), 175-181. doi:10.1080/14733140600874084

Markman, K. (2009). "So what shall we talk about": Openings and closings in chat-based virtual meetings. Journal of Business Communication, 46, 150-170. doi:10.1177/0021943608325751

Meredith, J., \& Stokoe, E. (2014). Repair: Comparing Facebook "chat" with spoken interaction. Discourse \& Communication, 8, 181-207. doi:10.1177/1750481313510815

Pojanapunya, P., \& Jaroenkitboworn, K. (2011). How to say "Good-bye" in Second Life. Journal of Pragmatics, 43, 3591-3602. doi:10.1016/j.pragma.2011.08.010

Raclaw, J. (2008). Two patterns for conversational closings in instant message discourse. Colorado Research in Linguistics, 21, 34-54.

Rintel, E. S., Pittam, J., \& Mulholland, J. (2003). Time will tell: Ambiguous non-responses on Internet Relay Chat. The Electronic Journal of Communication, 13(1). Retrieved from http://www.cios.org/EJCPUBLIC/013/1/01312.HTML

Robinson, J. (2001). Closing medical encounters: Two physician practices and their implications for the expression of patients' unstated concerns. Social Science \& Medicine, 53, 639-656. doi:10.1016/S0277-9536(00)00366-X

Sacks, H. (1992). Lectures on conversation (Vol. 1, 2). Oxford, England: Blackwell.

Schalken, F., Wolters, W., Tilanus, W., Gemert, M. V., Hoogenhuyze, C., Meijer, E., \& Postel, M. (2010). Handbook online counseling [Handboek online hulpverlening]. Houten, The Netherlands: Bohn Stafleu van Loghum.

Schegloff, E. (1987). Analyzing single episodes of interaction: An excercise in conversation analysis. Social Psychology Quarterly, 50, 101-114.

Schegloff, E., \& Sacks, H. (1973). Opening up closings. Semiotica, 8, 289-327. doi:10.1515/semi.1973.8.4.289

Schönfeldt, J., \& Golato, A. (2003). Repair in chats: A conversation analytic approach. Research on Language \& Social Interaction, 36, 241-284. doi:10.1207/S15327973RLSI3603_02

Sneijder, P., \& Te Molder, H. (2005). Moral logic and logical morality: Attributions of responsibility and blame in online discourse on veganism. Discourse and Society, 16, 675-696. doi:10.1177/0957926505054941

Stivers, T., \& Robinson, J. (2006). A preference for progressivity in interaction. Language in Society, 35, 367-392. doi:10.1017/S0047404506060179

Stommel, W. (2012). Salutations, closings and pronouns: Some aspects of recipient design in online counseling. Journal of Communication and Medicine, 9, 145-158.

Stommel, W., \& Van Der Houwen, F. (2013). Formulation in "trouble" chat sessions. Language@Internet, 10 (Article 3). Retrieved from http://www.languageatinternet.org/articles/2013/stommel 
Stommel, W., \& Van Der Houwen, F. (2014). Complaining and the management of "face" in online counseling. Qualitative Health Research, 24, 183-193. doi:10.1177/1049732313519706

Te Molder, H. (2005). "I just want to hear somebody right now": Managing identities on a telephone helpline. In C. Baker, M. Emmison, \& A. Firth (Eds.), Calling for help: Language and social interaction in telephone helplines (pp. 153-173). Amsterdam, The Netherlands: John Benjamins.

Vayreda, A., \& Antaki, C. (2009). Social support and unsolicited advice in a bipolar disorder online forum. Qualitative Health Research, 19, 931-942. doi:10.1177/1049732309338952

West, C. (2006). Coordinating closings in primary care visits: Producing continuity of care. In J. Heritage \& D. Maynard (Eds.), Communication in medical care: Interaction between primary care physicians and patients (pp. 379-415). Cambridge, England: Cambridge University Press. 